\title{
Different branches of Global Accounting and Accountants responsibilities: A study in brief spectrum
}

\author{
Rejaul Abedin \\ Accounting and Finance Department, North East University Bangladesh (NEUB)
}

\section{ABSTRACT}

Modern organizations are increasingly becoming more complex whether it is sole proprietorships, partnerships or Limited Liability Companies (LLC) (and in many cases global) thereby engendering the need for complete, transparent, reliable and accurate information that can be accessed quickly by the assistance of different branches of global professional accountants such as Certified Professional Accountant, Chartered Accountant, Certified Public Accountant, Management Accountant, Cost Accountant, Financial Accountant, General Accountant, Auditor, Tax Accountant, CA, CPA, CMA, CIMA, CFA, $\mathrm{CFO}$, ICPA and so on. Internationally most large business organizations are well organized by a broad and disparate set of shareholders. These shareholders require the information i.e. quantitative (financial) and qualitative (non-financial) relating to their various organizations in order to make ongoing decisions through financially like dividend or non-financially or strategic decisions - which can range from deciding to invest more and hold more shares, sell off part or all of their holdings, take critical decision on the management and boards of the financial institutions and banks etc. Besides, other stakeholders need the information to make decisions relating to lending, taxation, employee benefits and remuneration. It is essential that the quality of decisions that investors can 
make is largely dependent on the reliable and quality of information available to them. However, one thing that is common to all organizations is that the accountant plays a pivotal role towards the successful achievement of their strategic objectives by ensuring that the critical ingredient required for decision making is prepared and presented in the required format.

Keywords: Chartered Professional Accountant, Chartered Accountant, Management Accountant, Certified Public Accountant, Cost Accountant, Financial Accountant, General Accountant, Tax Accountant, CPA, CMA, CIMA, CFA, CFO, ICPA, ITP.

\section{INTRODUCTION}

Accounting profession has played a very vital role in ancient era and now playing a significant task in modern world. Accounting term itself holds many elements for business. Accounting subject itself has well set career for men and women residing in global village, after certifying in different field of accounting, potential or existing accountants may keep their eyes on top positions in manufacturing industry, corporate management, government, non-government organizations and general business. Accounting fulfills the basic need of every businessman, from the each monetary transaction, business deals through finance, to operations of assets question or addition everywhere accounting function involves. None of the business entity can successfully operate without the help of accounting or accountant. Therefore, Accounting or professional accountant so essential to all of our national and international business society. Even in small and medium business, individual use pen, pencil, paper and keep day to day business transactional and operational records. In large business organizations, modern accounting or financial software are used to operate. Men and women are directing these machines in the accounting process through manually or automation. Wise businessmen when in business rather he or she must have some basic accounting knowledge and skills though they should have hired professional accountants as well as tax accountants or practitioners from different branches of global accounting. Actually an accountant records and 
monitors the flow of money through a business operation of an organization. Accountant generally keep records in the way a business has grown and, after analyzing transaction's figures, suggests the perfect way it should go in the future. The tax accountants help their clients to assess individual or corporate taxes and aid clients to submit returns in time to government exchequer.

\section{Methodology of the study}

This research has approached a way such as the secondary data collection which includes required data and relevant information from research papers, journals, reports, books, magazines and online newspapers, websites etc. All data and information used in this study based on global accounting bodies and institutes websites and their journals where the respective institutes are based on globally so, it is almost impossible to reach out to collect information through primary data.

\section{Objectives of the Study}

The core objective of the study is to investigate the different branches of global accounting professionals and the below mentioned aims:

i. To understand the different branches of global accounting and accountants responsibilities.

ii. To find out the global accountants responsibilities from the different sectors and its branches.

iii. To identify the market areas of each professional accounting bodies.

iv. To recognize the level of influence and impact affecting by the global different branches of accountants.

v. To recommend the international accounting institutes for widely offerings global certifications \& memberships. And to make collaboration, affiliation with other compatible or homogeneous international accounting bodies.

\section{Limitations of the Study}

There are several aspects of this study could comprise a limitation in the research conducted. These are mentioned as follows:

a) Primary data or information is ignored due to access barriers in study on international accounting institutes or bodies. Those institutes are situated 
globally in different countries where author was in Bangladesh during his study so, it was impossible to take their face to face interview through set of formal questionnaire. Alternatively without asking direct queries to their concern officers it is tough to get proper information.

b) The name of "A to Z" Accounting Institutes or Accounting bodies name did not include in this research, merely highly important institute's name included in the research paper.

c) The lack of a sufficient database or difficulty in obtaining aimed data or the limited number of journals and articles dedicated to study on global accounting and accountants responsibilities.

d) This should be noted that the timeframe is very limited of this study.

\section{Professional Accountant}

A professional accountant is one who has acquired broad-based knowledge and skills of accounting practice, and has been formally admitted into a recognized body with formal charter, and made subject to rules of conduct that conform to the highest ideals of expert protocol. He holds his position by virtue of statute and professional competence, a position secured and bordered by law. He has been found worthy in character and learning, a fit and proper person, to be entrusted with the liberty to operate at the commanding heights of the nation's economy. He recognizes that he has a social contract with the wider society, yet he holds the confidence and trust of the people, borne out of his commitment to their highest good. $\mathrm{He}$ traces his connections to the best in international accounting practice world-wide, yet has his roots firmly embedded in a people's need for growth and development, and drive for economic emancipation. He is a man of ideas, a critique extra-ordinary, an intellectual in his own rights, a storehouse of knowledge, skills and competencies. That is the professional accountant.

Professional accountants, as a first and preliminary measure, offer to the nation, those standards and criteria that define true professionalism. Professionals are known by the key attributes of discipline, competence and integrity. These qualities stand out true professionalism from mere pedestrianism. The first, Competence is the hallmark of professionalism. It is borne out by vast body of knowledge and skills acquired from a lifetime of study and practice. The second attribute is Discipline - the price tag of professionalism. Discipline involves mastery of self and elements of time 
management, hard work, persistence, honesty and responsibility. The third attribute is integrity - the ultimate test of professionalism. Professionals are persons committed to standards of integrity and performance that cannot be altered to suit people's tastes or what they are willing to pay for - men who stay true to what they were called to do, stubbornly refusing to do the easy work that the age asks of them (Peterson, 1996). And the professional accountant presents this role-definition as a guide to Global business leaders.

\section{Accountants responsibilities}

There are many types of accountants available in the world. One deal with cost matters, other deals with audit matters, rest deals with pure accounting and financial matters but the main goal of those accountants are almost same it is means to help the business owners, maximize organizational wealth or profit in broad spectrum, and to prepare the books of accounts through professional look for organizational internal and external users.

Truly a certified professional accountant in business (profit or nonprofit oriented organization) is an invaluable asset to the company. These accountants employ an inquiring mind to their work founded on the basis of their skills, knowledge of the company's financial issues. By the application of their skills and intimate understanding of the company and the environment in which it operates, professional accountants in business ask challenging questions and try to solve problems through their strategic decisions. In broad spectrum, their depth training \& skills in accounting specially enables them to adopt a pragmatic and objective approach to solving issues. Thus, this sort of professional skills is valuable asset to management, particularly in small and medium enterprises where the professional accountants are often professionally qualified members of the global accounting institutes.

In essence, Accountancy professionals in business assist with corporate strategy, provide advice and help businesses to reduce costs, improve their top line and mitigate risks. As board of directors, professional accountants in business represent the interest of the owners of the company (i.e., shareholders in a public company). Their roles ordinarily include: governing the organization (such as, approving annual budgets and accounting to the stakeholders for the company's performance); appointing the chief executive; and determining management's compensation. For instance, as a chief financial officer, professional accountants have oversight over all matters relating to the 
company's financial health. This includes creating and driving the strategic direction of the business to analyzing, creating and communicating financial information. Because internal auditors, professional accountants provide independent assurance to management that the organization's risk management, governance and internal control processes are operating effectively. Also they offer advice on areas for enhancements. In the public sector, professional accountants in government shape serving in finalizing fiscal policies that had farreaching impacts on the government institutes. Accountants in whole are tasked with the important role of imparting the skills, knowledge and ethical underpinnings of the profession to the next generation accountants.

\section{Different branches of Global Accounting and Accountant's responsibilities}

There are many branches of Accounting, where certified accountants playing significant roles with business accounting operations such Accountants names goes here.

\section{Management accountant}

The initial step to move forward turning into the management accountant is to gain a four year accounting bachelor education from college or university. The candidate needs to pass an exam to end up a Certified Management Accountant (CMA) or CIMA. Some regular responsibilities of the management accountant are budgeting and planning, monetary reporting, risk management, productivity or profitability analysis and substantially more. Additionally, technical accounting aptitudes, these professionals must have the capacity to sort out data and present it in a way that is basic for business officials to grasp.

The Management Accounting produces data fundamentally for internal use by the organization's administration. The data delivered is for the most part more definite than that created for outside use to empower successful association control and the satisfaction of the vital points and targets of the substance. Data might be in the shape spending plans and figures, empowering an undertaking to design successfully for its future or may incorporate an appraisal dependent on its past execution and results. The shape and substance of any report created in the process is absolutely upon the executives' prudence. 
The Management Accounting, actually, has a long and critical history of direct commitment to the arranging and control of hierarchical tasks. Apparently it has traditionally been a comprehensively engaged capacity working hand-inglove with the board basic leadership, having a noteworthy effect upon hierarchical system and results. Here, endeavors are made to ponder the powers and changes affecting upon our contemporary bookkeeping calling with a view to considering the changing profile of the management accounting and the going with changing jobs of the management accountants.

\section{Cost accountant}

The Cost accounting is a branch of the management accounting and includes the utilization of different strategies to screen and control costs. Its application is more suited to assembling concerns. The Cost accounting - measures and reports monetary and nonfinancial data identifying with the expenses of procuring or using assets in an association. The cost accounting gives data to both management accounting and financial accounting. The Cost Accountant examines each cost identified with labor, materials, production, shipping, management and more. This data is then accumulated and conveyed to business pioneers to enable them to distinguish manners by which they can enhance money related productivity. The Cost accountants must be outfitted with a four year college education in bookkeeping or back and be in control of solid math and insights aptitudes. It's additionally prescribed to obtain a standard licensure, for example, a CPA qualification, or a specific licensure, for example, the Certified Cost Accountant (CCA) accreditation.

\section{CPA (Certified Public Accountant)}

The certified Public Accountants (CPA) are upper-level Accountants who are perceived as specialists in an association's accounting records, taxes and monetary or financial standing. While a portion of their work involves taxes, their inclusion will in general be more top to bottom than simply working with taxes. A CPA's job is that of a confided in advisor, serving their customers plan and meet their money related objectives, while likewise aiding other financial issues. This could incorporate reviews and audits, counseling related fields, forensic accounting and additionally litigation administrations. Type of accounting service to the general public, and is viewed as more professional than 
private type of accounting. The Certified and non-certified public accountants can give accounting service or provide services in accounting administrations.

\section{Forensic accountant}

The Forensic Accounting is the utilization of accounting, auditing and analytical systems in instances of prosecution or debate. The Forensic Accounting go about as master observers in courtrooms in civil and criminal debate that require an evaluation of the monetary impacts of a misfortune or the identification of a budgetary misrepresentation. Normal litigations where The Forensic Accounting are enlisted incorporate protection claims, individual wound claims, associated misrepresentation and cases with expert carelessness in a financial issue (e.g. business valuation).

The Forensic Accounting is the forte practice region of accountancy that depicts commitment that outcome from real or foreseen question or litigation. "Forensic" signifies "appropriate for use in a court of law", and it is to that standard and potential result that measurable accountants by and large need to work. The Forensic accountants additionally alluded to as legal reviewers or insightful inspectors, frequently need to give master proof at the possible preliminary. The majority of the bigger Accounting firms, and in addition numerous medium-sized and boutique firms, have professional Forensic Accounting divisions. Inside these groups, there might be further subspecializations: some Forensic accountants may, for instance, simply spend significant time in insurance claims, individual wound claims, misrepresentation, development, or royalty audits.

\section{General Accountant}

Certified General Accountant (CGA) is an expert assignment allowed to Canadian bookkeepers. A man who meets the training, background and examination necessities of the Certified General Accountants of Canada (CGACanada) is qualified for utilize the expert assignment and include the letters "CGA" to their title. A CGA is together an individual from CGA-Canada and a provincial or regional CGA affiliation, or a CGA affiliation abroad. The CGAs serve all through the world in industry, trade $\&$ commerce, finance, government, public practice and the nonprofit sector. CGA-Canada is working with the Chartered Professional Accountants of Canada (CPA Canada) to coordinate tasks 
under the CPA standard in 2014. Those with a CGA designation will be naturally conceded the Chartered Professional Accountant (CPA) designation and are required to utilize both simultaneously until 2024, (noted as CPA, CGA) and after that acclimate to the CPA designation alone only for it. A general accountant regulates and keeps up an assortment of accounting and financial related capacities for people or associations. General accountants handle all accounting obligations, as opposed to have some expertise in one accounting discipline.

\section{Project accountant}

A project accountant is one who deals with an undertaking of project wise. This individual regulates all parts of a project that may influence the general expense or cost, preparing and collecting invoices, affirming costs or expenses, confirming workers' billable hours, arranging and keeping up spending plans and guaranteeing the group is meeting project deadlines. There are numerous kinds of projects that a task accountant may take a shot at, everything from another item dispatch to the development of another office. Undertaking project accountants ordinarily work with project directors or managers and other expert associates, so solid correspondence and interpersonal professional abilities are important. Most project Accounting hold something like a four year college education in accounting. A few businesses mostly prefer hiring accountants those who have certification, for example, a CPA or CMA certification.

The project Accounting refers to the utilization of accounting framework to follow the money related advancement of a venture through incessant monetary reports. The project Accounting is an indispensable part of the project management. It is a particular part of the management accounting with a prime spotlight on financial success of company's projects, for example, the launch of a new service or product. The project Accounting can be a wellspring of upper hand for undertaking focused organizations, for example, developer or construction firms. 


\section{Social Accountant}

Social Accounting, or else called CSR (Corporate Social Responsibility) Reporting and Sustainability Accounting, alludes to the way toward revealing ramifications of an association's exercises on its natural and social environment. Social Accounting is principally announced as Environmental Reports going with the yearly reports of organizations. Social Accounting is still in the beginning times of advancement and is viewed as a reaction to the developing environmental cognizance among general society at large, corporate and business social responsibility exposure.

Social accounting has to do with consolidating social and environmental effect into conventional financial accounting. It is identified with the triple main concern that has been embraced by numerous social business entrepreneurs and social oriented innovative organizations. In corporate culture, social accounting is firmly associated with corporate social responsibility (CSR).

\section{Investment accountant}

The Investment accountants must hold something like a four year college education in bookkeeping, fund, financial aspects or business. Numerous additionally proceed to acquire their CPA accreditation and some likewise turned out to be Personal Financial Specialists (PFS).

The Investment accounting, portfolio accounting or securities bookkeeping all equivalent words depicting the way toward representing an arrangement of investments, for example, securities, products, services as well as realtors, real estate held in a investment fund, for instance, a hedge fund or mutual fund.

\section{Financial Accountant}

Financial accounting is the way toward account recording, reporting and summarizing the horde of exchanges arises from business activities over period of time frame. These exchanges are summarized in the readiness of all financial statements, including the asset \& liability report, balance sheet, cash flow statement and income statement, which record the organization's operational performance over a period of time. 
A Financial Accountant is primarily responsible for running the accounting and monetary exercises of a business association. They break down the organizations economic stability and give budgetary data and financial information to different divisions. A Financial Accountant gives an account of costs, margins, productivity, and organization's expenditures.

\section{Tax Accountant}

Tax Accounting (TA) refers to accounting task for the tax associated matters. It is mainly governed by the tax rules of respective government through the tax laws of a jurisdiction. These rules are dissimilar from the rules which govern the preparation of financial statements for public exercise (i.e. GAAP). The Tax accountants (TA) thus adjust the financial statements prepared following by the financial accounting principles to account for the distinctions with rules prescribed by tax laws. As the Information is then used by the tax professionals to approximate tax liability of a company or individual and for tax planning purposes. A tax professional (TP) or ITP (Income Tax Practitioner) is particularly trained in the field of taxation. As for example, The U.S. Department of Treasury authorized tax professionals to represent taxpayers prior to all administrative levels of the IRS (Internal Revenue Service) for audits, revenue collections, and appeals.

\section{Chartered Accountant (CA)}

The Chartered accountant (CA) designation is familiar worldwide, and it refers to professional accountants who are trained, certified from Charter accounting body's to take on a number of specific activities within the area of accountancy. Their tasks comprise auditing financial statements \& accounts, filing of individual or corporate tax returns and financial advising. Around the globe, in the United States and in the Canada, In the Australia, the equivalent position is known as a certified public accountant ( CPA). The professional body that governs accounting workers was initially founded in Great Britain. There are now several associations that act as governing and accrediting bodies for these professionals, such as the Canadian Institute of Chartered Accountants and the Institute of Chartered Accountants in England and Wales (ICAEW). 


\section{What Chartered Accountants Do?}

There are four areas where Chartered Accountants (CA) serves. They are financial accounting and reporting, Auditing, taxation, and applied finance cum management accounting. The specialization an accountant chooses determines under which umbrella he or she works. The members of the Institute of Chartered Accountants (ICA) are known as the Fellow Chartered Accountants, Associate Chartered Accountants etc. In some cases they also self employed where they operating their own firms through auditing functions of firm's accounts. They maintain national or international accounting standards.

\section{Internal Auditor}

Internal audit is known a dynamic profession that involved in serving organizations to achieve their objectives. It is concerned with evaluating books of accounts records and improving the effectiveness of risk management, control and governance processes within an organization.

An internal auditor is an employee of a company who providing independent and objective evaluations of the organization's financial and operational business activities, including its corporate governance. On the other hand, an internal auditor is an accounting professional who acts independently to assess how efficient a organization's internal control structure is.

\section{CGMA (Certified Global Management Accountant)}

CGMA (Certified Global Management Accountant) is the most widely held management accounting designation in the world with more than 150,000 designees. It was established in 2012 by the AICPA and CIMA to recognize a unique group of management accountants who have already reached the highest benchmark of quality, goodwill and competence. The CGMA designation \& certification is built on extensive global research to maintain the highest relevance by employers and develop the competencies which is most in demand. CGMA designation holders qualify through rigorous education, competitive examination and practical experience required.

\section{GCMA (Global Certified Management Accountant):}

Global Certified Management Accountant (GCMA) earning accounting certification is a big step towards improving organization's marketability and company's business advancement. 


\section{Table 1: Global Accounting Institute Names \& their activities - At a glance}

\begin{tabular}{|c|c|c|c|}
\hline $\begin{array}{l}\text { Name of the Accounting } \\
\text { Institutes }\end{array}$ & $\begin{array}{l}\text { Offered } \\
\text { Degrees \& } \\
\text { Membership } \\
\text { Status }\end{array}$ & $\begin{array}{l}\text { Country name/ } \\
\text { where operates }\end{array}$ & $\begin{array}{l}\text { Specialized } \\
\text { Areas }\end{array}$ \\
\hline $\begin{array}{l}\text { Association of International } \\
\text { Certified Professional } \\
\text { Accountants www.aicpa.org } 8\end{array}$ & $\begin{array}{l}\text { CPA, CGMA, } \\
\text { PFS, CFF, CITP, } \\
\text { CEIV. } \\
\text { Memberships in } \\
\text { different levels }\end{array}$ & $\begin{array}{l}\text { USA, Offers } \\
\text { Certifications } \\
\text { globally }\end{array}$ & $\begin{array}{l}\text { Public } \\
\text { Accountants }\end{array}$ \\
\hline $\begin{array}{l}\text { The Association of Chartered } \\
\text { Certified Accountants } \\
\text { www.accaglobal.com }\end{array}$ & $\begin{array}{l}\text { ACCA, CPD, } \\
\text { Memberships }\end{array}$ & $\begin{array}{l}\text { UK, Offers } \\
\text { Certifications } \\
\text { globally }\end{array}$ & $\begin{array}{l}\text { Chartered } \\
\text { Accountants }\end{array}$ \\
\hline $\begin{array}{l}\text { Accountants Association in } \\
\text { Poland (AAP), Institute of } \\
\text { Professional Certification for } \\
\text { Accountants www.skwp.pl/en }\end{array}$ & $\begin{array}{l}\text { CA (Certified } \\
\text { Accountant) }\end{array}$ & Poland, Europe & Accountant \\
\hline $\begin{array}{l}\text { The Institute of Cost and } \\
\text { Management Accountants of } \\
\text { Bangladesh (ICMAB) } \\
\text { www.icmab.org.bd }\end{array}$ & $\begin{array}{l}\text { CMA, Taxation, } \\
\text { Memberships }\end{array}$ & Bangladesh & $\begin{array}{l}\text { Cost \& } \\
\text { Management } \\
\text { Accountants }\end{array}$ \\
\hline $\begin{array}{l}\text { The Institute of Chartered } \\
\text { Accountants of Bangladesh } \\
\text { (ICAB) www.icab.org.bd }\end{array}$ & CA, Memberships & Bangladesh & $\begin{array}{l}\text { Public } \\
\text { Practice, } \\
\text { Auditing }\end{array}$ \\
\hline $\begin{array}{l}\text { Chartered Professional } \\
\text { Accountants } \\
\text { www.cpacanada.ca/en }\end{array}$ & $\begin{array}{l}\text { CPA, } \\
\text { Memberships }\end{array}$ & Canada & $\begin{array}{l}\text { Public } \\
\text { Accountants }\end{array}$ \\
\hline $\begin{array}{l}\text { The Institute of Chartered } \\
\text { Accountants of India (ICAI) } \\
\text { www.icai.org }\end{array}$ & CA, Memberships & India & $\begin{array}{l}\text { Chartered } \\
\text { Accountants }\end{array}$ \\
\hline $\begin{array}{l}\text { The Institute of Cost } \\
\text { accountants of India } \\
\text { https://icmai.in }\end{array}$ & $\begin{array}{l}\text { CAT, Certificate } \\
\text { in Accounting } \\
\text { Technicians } \\
\text { (CAT), Taxation, } \\
\text { CMA, } \\
\text { Memberships }\end{array}$ & India & $\begin{array}{l}\text { Cost } \\
\text { Accountants }\end{array}$ \\
\hline $\begin{array}{l}\text { Chartered Institute of } \\
\text { Management Accountants } \\
\text { www.cimaglobal.com }\end{array}$ & $\begin{array}{l}\text { CIMA, } \\
\text { Memberships }\end{array}$ & $\begin{array}{l}\text { UK, Offers } \\
\text { Certifications } \\
\text { globally }\end{array}$ & $\begin{array}{l}\text { Management } \\
\text { Accountants, } \\
\text { CIMA joined } \\
\text { with AICPA- } \\
\text { the American } \\
\text { Institute of } \\
\text { Certified } \\
\text { Public } \\
\text { Accountants } \\
\text { and CIMA. }\end{array}$ \\
\hline
\end{tabular}




\begin{tabular}{|c|c|c|c|}
\hline $\begin{array}{l}\text { The Institute of Chartered } \\
\text { Accountants in England and } \\
\text { Wales (ICAEW) } \\
\text { www.icaew.com }\end{array}$ & $\begin{array}{l}\text { ACA, CA, CPD, } \\
\text { Memberships }\end{array}$ & $\begin{array}{l}\text { UK, England, Offers } \\
\text { Certifications } \\
\text { globally }\end{array}$ & $\begin{array}{l}\text { Chartered } \\
\text { Accountants, } \\
\text { Auditing, } \\
\text { Public } \\
\text { Practice } \\
\text { Certificate } \\
\text { (PPC) in } \\
\text { Europe and } \\
\text { globally }\end{array}$ \\
\hline $\begin{array}{l}\text { Institute of Management } \\
\text { Accountants www.imanet.org }\end{array}$ & $\begin{array}{l}\text { CMA, } \\
\text { Memberships }\end{array}$ & $\begin{array}{l}\text { USA, Offers } \\
\text { Certifications } \\
\text { globally }\end{array}$ & $\begin{array}{l}\text { CMA® } \\
\text { (Certified } \\
\text { Management } \\
\text { Accountant) }\end{array}$ \\
\hline $\begin{array}{l}\text { Institute of Certified } \\
\text { Management Accountants, } \\
\text { Australia (ICMA) } \\
\text { www.cmawebline.org }\end{array}$ & $\begin{array}{l}\text { AMA, RCA, } \\
\text { CAT, GMA, } \\
\text { CMA, Certified } \\
\text { Global Business } \\
\text { Analyst (CGBA), } \\
\text { Memberships }\end{array}$ & $\begin{array}{l}\text { Australia, Offers } \\
\text { Certifications } \\
\text { globally }\end{array}$ & $\begin{array}{l}\text { CMA } \\
\text { (Certified } \\
\text { Management } \\
\text { Accountant) }\end{array}$ \\
\hline $\begin{array}{l}\text { CPA Australia } \\
\text { www.cpaaustralia.com.au }\end{array}$ & $\begin{array}{l}\text { CPA, Certified } \\
\text { Practicing } \\
\text { Accountant } \\
\text { (CPA), CPD, } \\
\text { Memberships }\end{array}$ & $\begin{array}{l}\text { Australia, Offers } \\
\text { Certifications } \\
\text { globally }\end{array}$ & $\begin{array}{l}\text { Public } \\
\text { Accountants }\end{array}$ \\
\hline $\begin{array}{l}\text { The Institute of Cost \& } \\
\text { Management Accountants of } \\
\text { Pakistan (ICMA Pakistan) } \\
\text { www.icmap.com.pk }\end{array}$ & $\begin{array}{l}\text { CPD, CMA, } \\
\text { Memberships }\end{array}$ & Pakistan & $\begin{array}{l}\text { Management } \\
\text { Accountants }\end{array}$ \\
\hline $\begin{array}{l}\text { Institute of Singapore Chartered } \\
\text { accountants (ISCA) } \\
\text { https://isca.org.sg }\end{array}$ & $\begin{array}{l}\text { CA, ATTS, } \\
\text { Memberships }\end{array}$ & Singapore & $\begin{array}{l}\text { Chartered } \\
\text { Accountants }\end{array}$ \\
\hline $\begin{array}{l}\text { The Chartered Institute of } \\
\text { Management Accountants of } \\
\text { Nigeria www.cimanigeria.com }\end{array}$ & $\begin{array}{l}\text { CMA, CIMA, } \\
\text { Memberships }\end{array}$ & $\begin{array}{l}\text { Nigeria, Offers } \\
\text { membership globally }\end{array}$ & $\begin{array}{l}\text { Chartered } \\
\text { Management } \\
\text { Accountants } \\
\end{array}$ \\
\hline $\begin{array}{l}\text { The Institute of Chartered } \\
\text { Accountants of Nigeria } \\
\text { www.icanig.org }\end{array}$ & $\begin{array}{l}\text { ICAN, CIPFA, } \\
\text { Memberships }\end{array}$ & Nigeria & $\begin{array}{l}\text { Chartered } \\
\text { Accountants }\end{array}$ \\
\hline $\begin{array}{l}\text { The South African Institute of } \\
\text { Chartered Accountants } \\
\text { (SAICA) www.saica.co.za }\end{array}$ & $\begin{array}{l}\text { CA(SA), } \\
\text { AGA(SA), } \\
\text { AT(SA), } \\
\text { Memberships }\end{array}$ & South Africa & $\begin{array}{l}\text { Chartered } \\
\text { Accountants }\end{array}$ \\
\hline $\begin{array}{l}\text { The Institute of Chartered } \\
\text { Accountants of Scotland } \\
\text { www.icas.com }\end{array}$ & $\begin{array}{l}\text { CA, ICAS } \\
\text { Memberships }\end{array}$ & $\begin{array}{l}\text { Scotland, United } \\
\text { Kingdom }\end{array}$ & $\begin{array}{l}\text { CA, Chartered } \\
\text { Accountants }\end{array}$ \\
\hline $\begin{array}{l}\text { Institute of Chartered } \\
\text { Accountants Ireland (ICAI) } \\
\text { www.charteredaccountants.ie } \\
\end{array}$ & CA, Memberships & Ireland & $\begin{array}{l}\text { CA, Chartered } \\
\text { Accountants }\end{array}$ \\
\hline $\begin{array}{l}\text { GCMA certification awarded } \\
\text { by the Scottish Qualifications } \\
\text { Authority (SQA) } \\
\text { https://iqnglobal.com/gcma/ }\end{array}$ & $\begin{array}{l}\text { GCMA, SCQF } \\
\text { (Level 8), } \\
\text { Certifications } \\
\text { only }\end{array}$ & Scotland & $\begin{array}{l}\text { Global } \\
\text { Certified } \\
\text { Management } \\
\text { Accountant }\end{array}$ \\
\hline Institute of certified general & CGA Bangladesh, & Bangladesh & \\
\hline
\end{tabular}




\begin{tabular}{|l|l|l|l|}
\hline $\begin{array}{l}\text { accountant of Bangladesh } \\
\text { (ICGAB) http://icgab.org }\end{array}$ & Memberships & & \\
\hline $\begin{array}{l}\text { The Institute of Certified } \\
\text { General Accountants, Pakistan } \\
\text { (CGA-PAKISTAN®) } \\
\text { http://cgaglobal.org }\end{array}$ & $\begin{array}{l}\text { CGA Pakistan, } \\
\text { Memberships }\end{array}$ & Pakistan & $\begin{array}{l}\text { General } \\
\text { Accountant }\end{array}$ \\
\hline $\begin{array}{l}\text { Iranian Association of Certified } \\
\text { Public Accountants (IACPA) } \\
\text { http://en.iacpa.ir }\end{array}$ & $\begin{array}{l}\text { CPA, } \\
\text { Certifications, } \\
\text { Memberships }\end{array}$ & Iran & $\begin{array}{l}\text { Public } \\
\text { Accountant }\end{array}$ \\
\hline $\begin{array}{l}\text { The American Board of } \\
\text { Accounting® (ABFA) } \\
\text { http://abfa.us/about_us }\end{array}$ & $\begin{array}{l}\text { Forensic } \\
\text { Accountant }\end{array}$ & $\begin{array}{l}\text { USA, Offers } \\
\text { Certifications } \\
\text { globally }\end{array}$ & $\begin{array}{l}\text { Certified } \\
\text { Forensic } \\
\text { Accountant } ®\end{array}$ \\
\hline $\begin{array}{l}\text { The Institute of Internal } \\
\text { Auditors. } \\
\text { https://global.theiia.org }\end{array}$ & $\begin{array}{l}\text { CIA, CGAP, } \\
\text { CFSA, CRMA, } \\
\text { Certifications, } \\
\text { Memberships }\end{array}$ & $\begin{array}{l}\text { USA, Offers } \\
\text { Certifications } \\
\text { globally }\end{array}$ & $\begin{array}{l}\text { Internal } \\
\text { Auditors }\end{array}$ \\
\hline
\end{tabular}

Source: Google Search Secondary Data (2018)

\section{Table 2: Global Tax Accounting Institute Names \& Activities - At a glance}

The tax accountants generally practitioners of Income Tax, Federal Tax, corporate tax, wealth tax, tax holidays, tax rebates or tax exemptions, those who are in public practice is called ITP (Income Tax Practitioner), they assists their clients to submit yearly returns to the respective government tax agencies.

\begin{tabular}{|l|l|l|l|}
\hline $\begin{array}{l}\text { Name of the Tax } \\
\text { Accounting Institutes }\end{array}$ & $\begin{array}{l}\text { Offered Degrees } \\
\text { \& Membership } \\
\text { Status }\end{array}$ & $\begin{array}{l}\text { Country name/ } \\
\text { where operates }\end{array}$ & $\begin{array}{l}\text { Specialized } \\
\text { Areas }\end{array}$ \\
\hline $\begin{array}{l}\text { The Tax Institute, } \\
\text { www.taxinstitute.com.au }\end{array}$ & $\begin{array}{l}\text { CTA, Chartered Tax } \\
\text { Advisers, } \\
\text { memberships }\end{array}$ & Australia & $\begin{array}{l}\text { Australian Tax } \\
\text { Issues, Tax } \\
\text { Certifications }\end{array}$ \\
\hline $\begin{array}{l}\text { The Chartered Institute of } \\
\text { Taxation (CIOT) } \\
\text { www.tax.org.uk }\end{array}$ & $\begin{array}{l}\text { CTA, ATT, CIOT, } \\
\text { Chartered Tax } \\
\text { Adviser, }\end{array}$ & $\begin{array}{l}\text { UK, Offers } \\
\text { Certifications } \\
\text { globally }\end{array}$ & Tax Certifications \\
\hline $\begin{array}{l}\text { The Singapore Institute of } \\
\text { Accredited Tax } \\
\text { Professionals Limited } \\
\text { (SIATP) } \text { www.siatp.org.sg }\end{array}$ & $\begin{array}{l}\text { Accredited Tax } \\
\text { Advisor (ATA), } \\
\text { Accredited Tax }\end{array}$ & $\begin{array}{l}\text { Practitioner (ATP) } \\
\text { and Accredited Tax } \\
\text { Cractitioner } \\
\text { Certifications } \\
\text { globally }\end{array}$ & $\begin{array}{l}\text { Continuing } \\
\text { Professional } \\
\text { Education (CPE), } \\
\text { Continuing } \\
\text { Professional } \\
\text { Development } \\
\text { (CPD), }\end{array}$ \\
\hline $\begin{array}{l}\text { The Institute For } \\
\text { Professionals In Taxation } \\
\text { www.ipt.org }\end{array}$ & $\begin{array}{l}\text { CMI, CCIP, } \\
\text { memberships }\end{array}$ & $\begin{array}{l}\text { USA, Offers } \\
\text { Certifications } \\
\text { globally }\end{array}$ & $\begin{array}{l}\text { Publication, Online } \\
\text { Registration }\end{array}$ \\
\hline Tax Executives Institute & Federal tax Course, & USA, Offers & Online Registration \\
\hline
\end{tabular}




\begin{tabular}{|c|c|c|c|}
\hline (TEI), www.tei.org & $\begin{array}{l}\text { US international Tax } \\
\text { Course, } \\
\text { memberships }\end{array}$ & $\begin{array}{l}\text { Certifications } \\
\text { globally }\end{array}$ & for membership \\
\hline $\begin{array}{l}\text { The Irish Tax Institute } \\
\text { www.taxinstitute.ie }\end{array}$ & $\begin{array}{l}\text { CTA (Chartered Tax } \\
\text { Adviser), Tax } \\
\text { Technician } \\
\text { Qualification }\end{array}$ & Ireland & $\begin{array}{l}\text { Tax Professional } \\
\text { Development }\end{array}$ \\
\hline $\begin{array}{l}\text { European Tax Adviser } \\
\text { Federation AISBL - ETAF } \\
\text { www.etaf.tax }\end{array}$ & $\begin{array}{l}\text { Institutional } \\
\text { Memberships }\end{array}$ & Belgium, Europe & $\begin{array}{l}\text { Tax Events, } \\
\text { Conferences, EU } \\
\text { initiatives in tax }\end{array}$ \\
\hline $\begin{array}{l}\text { The South African Institute } \\
\text { of Tax Professionals } \\
\text { (SAIT) www.thesait.org.za }\end{array}$ & $\begin{array}{l}\text { Tax Professional, } \\
\text { Tax Technician, } \\
\text { Memberships }\end{array}$ & $\begin{array}{l}\text { South Africa, } \\
\text { Offers } \\
\text { Certifications } \\
\text { globally }\end{array}$ & $\begin{array}{l}\text { Honorary Tax } \\
\text { Fellowships }\end{array}$ \\
\hline $\begin{array}{l}\text { Bangladesh Tax Training } \\
\text { Institute http://taxbd.org }\end{array}$ & $\begin{array}{l}\text { Training on Tax, } \\
\text { Training on VAT }\end{array}$ & Bangladesh & $\begin{array}{l}\text { Short Training on } \\
\text { Tax and VAT }\end{array}$ \\
\hline $\begin{array}{l}\text { NBR (National Board of } \\
\text { Revenue), Bangladesh } \\
\text { http://nbr.gov.bd }\end{array}$ & $\begin{array}{l}\text { Registration } \\
\text { (ITPRF-01), Income } \\
\text { Tax Practitioner } \\
\text { (ITP) Examination } \\
\text { (Written \& Viva } \\
\text { voce) }\end{array}$ & $\begin{array}{l}\text { Bangladesh } \\
\text { Government } \\
\text { Initiative }\end{array}$ & $\begin{array}{l}\text { Income Tax Public } \\
\text { Practice License } \\
\text { and Certification, } \\
\text { BD Income Tax } \\
\text { Ordinance \& rules, } \\
1984\end{array}$ \\
\hline $\begin{array}{l}\text { Institute of Tax } \\
\text { Practitioners of India } \\
\text { http://aitpi.org }\end{array}$ & $\begin{array}{l}\text { Income Tax } \\
\text { Practitioner (ITP) } \\
\text { certificate Courses, } \\
\text { Training, } \\
\text { Membership }\end{array}$ & India & $\begin{array}{l}\text { Income Tax } \\
\text { Trainings }\end{array}$ \\
\hline
\end{tabular}

Source: Google Search Secondary Data (2018)

\section{The Role of Professional Accounting Bodies in Promoting Global Professional Accountants}

Professional accounting bodies globally have the significant mandate of representing, promoting and enhancing the global accountancy profession. At the national level, the professional accounting body is the strategic voice for the nation's professional accountants; this includes all professional accountants both in practice independently and in business. Because they play different roles in the society, the overall status of the accountancy profession can only be strengthened when both professional accountants in private practice and in business sectors are well-perceived by society. Since professional accountants in business are often the only members of staff who are professionally trained and qualified in accounting area for the development of accounting operations of organizations, they are more likely to rely on their professional accounting body for assistance in carrying out their work. They will look to the professional accounting body to provide them with the support and resources they need in doing their daily jobs 
and to keep their skills up-to-date. For instance, professional accountants in business may look to their subject matter experts in the accounting body for advice on how to handle ethical dilemmas. They will besides be dependent on their accounting body to provide continuous professional development training initiatives to keep their knowledge and skills current.

Certified or Accredited Management accountants (ACA) can be key players in organizational change. Certified Accountants has identified the different roles they take up in change processes and a leadership approach that is effective for professionals engaged in accounting profession for change in their own organizations as well as for their client's organizations.

\section{Different working fields for Global Accountants}

Businesses that need \& employ Global Professional Accountants: Many types of businesses need global professional accountants to audit their accounts and finances and balance their books of accounts on a daily basis for specific fiscal periods. The types of business companies or non-trading organizations that employ professional accountants all have a few things in familiar. They deal with complex accounting and financial systems; they monitor and check, verify highvolume business or non-business transactions, or both. Job seeker accountant or auditor can always be able to find an available accounting or auditing position in one of these high demand industries.

Globally across a variety of business and industry sectors requires highly trained or certified professional accountants, the potential industries name are appended below: -

1. Academies

2. Agriculture and rural business

3. Authorized funds

4. Aviation

5. Banking

6. Charities SORP

7. Charities

8. Churches and other places of worship

9. College and Universities

10. Education 
11. Football clubs

12. Film industry

13. Friendly, mutual and co-operative societies

14. Government and resource accounting

15. Government Agencies

16. Healthcare profession or providers

17. Hospitality Businesses

18. Investment trusts

19. Insurance

20. Leasing and asset finance

21. Limited liability partnerships

22. Local authorities

23. Oil, gas and mining

24. Pharmaceutical industry

25. Pension schemes

26. Registered social housing providers

27. Retail Stores

28. Solicitors

29. Service charges and service charge accounts.

\section{Outcomes/Findings of the study:}

Certifications may differ from Accounting institute to institute located globally but their operational outcomes are primarily alike to provide authenticate financial information to the financial reports users through internally and externally, internal Users are owners, management, employees, shareholders etc. External users are investors, creditors, Government monitoring agencies or institutes, member of non-profit organizations, consumers, \& research scholars and so on. Say for example, CA (Chartered Accountant) and CPA (Certified Public Accountant) certifications available in the global arena where both are performing preparing books of accounts and auditing in same ground and area. CPA mainly works for current financial issues, accounts payable, tax filings and company's payroll account, in a word, CPAs may work for individuals, government agencies, and accounting firms, as well as corporations. CMA (Certified or Chartered Management Accountant) is greatly focused on cost accounting, strategic financial projections \& assisting in the planning of future business endeavors, keeping accounting - financial records, planning for future income and expenditures and management issues. Though job responsibilities of 
such accountants have broad range, budgeting control, handling taxation (individual income taxes and corporate taxes), managing assets (Acquiring new assets, disposal of old assets and computing their depreciations during the year), aiding in strategic planning and so on. CA, CMA, CPA, CIMA certified holders generally serves in the seniors management positions as such $\mathrm{CFO}$, Controller, Director of Accounting or Finance, Senior Accountant, some of them are also doing general financial issues i.e. company's payroll accounts, cost management \& controls etc. Moreover, CMA or CIMA will bestow directly with management, owners, CEOs and advise on appropriate \& proficient financial planning, control, and decision making.

Table 1 showed information on Global Accounting Institute Names \& their activities - At a glance and Table 2 showed information on Global Tax Accounting Institute Names \& Activities - At a glance.

Recommendation: It is observed that in many countries professional accounting organizations are only offering their certifications and membership facilities within their home country; they don't have any e-learning or distance learning education in academic or professional level. So, in this context, I recommended themselves to make an announce globally that they have offers for the international students for their programs, courses using their website itself. If this happens, then job market for their professional accountants will be higher than past, percentage of Job availability in the international market is mentionable for the certified accountants. Some countries have management accountants certifications, cost accountants certifications, financial management accountants certifications but they only offers these to their local students in this connection they are showing causes that we are currently offers these courses through our local languages only. If such barrier exists then their qualified accountants will not able to introduce themselves into the global arena.

On the one hand, it is found that some professional accounting institutes even do not maintain international collaboration, global affiliation to create market and to promote brand their accounting degrees internationally. For global affiliation and collaboration the name of potential accounting bodies may include SAFA (India), CAPA (Malaysia), IFAC, CIMA \& CMA (USA), ICAEW (England), CPA (Ireland), CIPEA (UK), CMA (Australia), CPA (Australia), CPA (Canada), IASB (UK), IFRS (UK), ACCA (UK), IICPA (USA), PAFA, SAIPA (South Africa), etc. It is suggested that the accounting institutes should be affiliated and collaborated with highly compatible ones, say for instance, 
CMA ought to be joined with Certified Management Accountants Institutes or Chartered Cost and Management Accountants not with Chartered Accountants firms.

On the other hand, the aforementioned accounting professional institutes may introduce comprehensive accounting software package like QuickBooks, Tally, FreshBooks, Sage 50Cloud, Accounting by wave, FinancialForce Accounting, LedgerLite, ActivityHD, Accounting Xpert, Traverse, Activo, eZee Frontdesk, and so on. In this regard, they can introduce their own brand's accounting software and market their software globally through licensing version. AIS (Accounting and Information System), Accounting and Information System both should merge together though in this name "AIS" many books readily available in global market to read and this subject is included in the curriculum of Business studies as academic programs for accounting certifications but the advantages must be utilized by the global professional accounting institutes.

\section{CONCLUSION}

The Certified Public Accountant (CPA) or Certified Professional Accountant (CPA) aids in ensuring the quality of accounting and financial reporting but cannot be over emphasized or overstated. Although Management is responsible for the accounting and financial information produced by their respective company. Accountants are in the frontline of safeguarding the integrity, reliability of accounting and financial reporting. Hence, an accountant is an important asset to the company as he has the key trained skills that required speaking the language of business.

Indeed, every accountant in the industry is a leader. Amongst other key functions performed, leaders motivate and get people to achieve targets or goals (Koontz, O’Donnell \& Weihrich 1984). As a leader, an accountant must strive to create an upward spiral; Weir (2015). The environment could be one of mediocrity, failure or success. Where a leader creates an environment of success, then he/she and the people being led will succeed as well, which strengthens the environment for future success. The upward spiral therefore continues.

Conventionally, the role of Accountant in Business organization involves activity in regard with implementing and maintaining operational controls, providing analytical support for strategic planning and decision making and ensuring that effective risk management processes are in place. The 
responsibility of the Accountant in Business entity is therefore, critical to the financial health as well as the reputation and credibility of the business organization and its management. Accountant must nursing an respective organizations as fully fledged professional Accountants and be ready to take up the multiple challenges of different positions as the performance expectations are high in modern organizations. The value of professional accountants will be measured by the extent to which they are perceived to be accountable not only to their own organizations where the self-employed but more importantly to the public where they works professionally say for example auditing and preparing books of accounts maintaining and following accounting \& financial full set of standards. Eventually, tax accountants or tax practitioners are mainly responsible to deal with individual's and corporate tax file returns preparation to submit the same file to respective government tax authorities, globally this practices nowadays widely going on. Hence, contribution of tax consultants or tax accountants should not be ignored. 


\section{References:}

Aoun C, Vatanasakdakul S, Li Y (2010) AIS in Australia: UTAUT application \& cultural implication. ACIS 2010 Proceedings Paper pp: 1-12. [ Links ]

Collins, K. (2015). Exploring Business, v. 1.0. Retrieved from catalog.flatworldknowledge Dot com [ [ Links ]

Drury, C. (2009): Management accounting for business (4th Edition). United Kingdom. Cengage Learning EMEA

Davis, S. (2015) what role does an accountant play in business operations? Retrieved from Small Business Chron Dot Com [ Links ]

Ferran C, Salim R (2011) IAC accounting data model: a better data structure for computerized accounting systems. Rev Bus Info Syst 8: 109-120. [ Links ]

Grande UE, Estebanez PR, Colomina MC (2010) The impact of accounting information on performance measures: empirical evidence in Spanish SMEs. The Int J Digit Account $\underline{\text { Res 11: 25-43. [ Links ] }}$

Hopwood. A.G. (2008). Management accounting research in a changing world. Journal of Management Accounting Research, 20(1),3-13. [ [ Links ]

Okoye, A.E. (2011). Cost Accountancy: Management operational applications (second edition). Benin City. Mindex Publishing Co Ltd

Institute of Management Accountants. IMA. (2008). Definition of management accounting. United States of America: Institute of Management Accountants, IMA. [ Links ]

Ittner. C. D.. \& Larcker. D. F. (2001). Assessing empirical research in managerial accounting: a value-based management perspective. Journal of Accounting and Economics, 32(1-3),349-410. [ Links ]

Tahai. A.. \& Mever. M. J. (1999). A revealed preference studv of management journals' direct influences. Strategic Management Journal, 20(3),279-296. [ Links ]

\section{Websites:}

www.accountingtoday.com/magazine/

www.cpajournal.com/tag/accounting/

www.cgma.org/resources/reports/globalmanagementaccountingprinciples.html

www.intheblack.com/articles/2018/07/05/rise-of-management-accountant

https://www.ifac.org/news-events/2013-10/roles-and-importance-professionalaccountants-business 
Vol. 26, No. 2 December 2018 CCentre for Indonesian Accounting and Management Research Brawijaya University 